\title{
The Impact of Portfolio Assessment on EFL Learners' Reading Comprehension Ability
}

\author{
Mahshid Rostami Charvade ${ }^{1}$, Shahrokh Jahandar ${ }^{1} \&$ Morteza Khodabandehlou $^{1}$ \\ ${ }^{1}$ Islamic Azad University-Tonekabon Branch, Iran \\ Correspondence: Mahshid Rostami Charvade, Islamic Azad University- Tonekabon Branch, Iran. E-mail: \\ rostami90mahshid@yahoo.com
}

Received: December 24, 2011 Accepted: May 21, 2012 Online Published: July 1, 2012

doi:10.5539/elt.v5n7p129 URL: http://dx.doi.org/10.5539/elt.v5n7p129

\begin{abstract}
The aim of this study is to investigate the effectiveness of portfolio assessment on EFL learners' reading comprehension ability.50 EFL language learners at intermediate level all female from a private institute were selected for this purpose. Then they were randomly divided into the control and experimental group. The control group received the traditional assessment while the experimental group received the portfolio assessment. Two reading comprehension tests as pretest and posttest were given to the students of both groups to find out their reading comprehension ability at the beginning and at the end of the study and the treatment. The results of data analysis revealed that the students in the portfolio assessment group outperformed the students in the control group in their reading comprehension ability. Finally the findings of this study suggest that portfolio assessment empowers students 'reading comprehension ability.
\end{abstract}

Keywords: portfolio, EFL instruction, EFL assessment, alternative assessment, reading assessment, traditional assessment

\section{Introduction}

In recent years a reform has happened in the era of evaluation .It is shift from testing to assessment. Assessment is generally seen as one of the key challenges in the field of learning. Assessment, in the broad sense, means "any methods used to better understand the current knowledge that a student possesses" (Collins\& O'Brien, 2003, p. 29).

According to Crooks (2001), assessment is "any process that provides information about the thinking, achievement or progress of students" (p. 1). Because assessment is important in teaching and learning, every teacher should assess his/her students' learning regularly.

Some of the methods which teachers use to measure their students' learning are paper and pencil tests standardized tests, oral presentations, and question-and-answer activities. Therefore, teachers spend a great deal of their class time engaged in one type of assessment or another (Stiggins, 2001).

On the other hand, assessment of students entails using a well organized system, namely tests, to make judgments about the students' achievement (Gronlund \& Linn, 1990). While this type of assessment is a mainstay of educational programs educators and critics from various backgrounds have raised a number of concerns about its usefulness as the primary measure of students. There are many reasons for undesirability of traditional assessment .student' knowledge is evaluated by one or two single scores.

This element makes students rely on their memorization ability and reproduce these piece of information from their memory on the exam to score high and after the exam this information disappeared. This traditional assessment distracts the students from meaningful learning. Also many other factors may influence students' performances like anxiety, stress.

Today there are innovations in assessment procedures, where the change is from summative assessment to formative assessment. These innovations involve thinking of alternatives, which require questioning the learning process and using learning and assessment activities together rather than habitual testing applications.

Boud (1995) stresses that the assessment process shouldn't be thought only as an instrument to give students a diploma, but it should also be a process that leads up to student development and better learning conditions and applications. Such alternative views on assessment have given rise to new approaches like a self -assessment.

It has been argued that self assessment serves as an effective language learning strategy to promote autonomous 
language learning because it encourages language learners to assess their learning progress and in turn helps them to stay focused on their own learning (Chamot130 \& O'Malley, 1994; Chen, 2005; O’Malley \& Pierce, 1996; Oscarson, 1997).

The proponents of self assessment strategies maintain that participating in self assessment can help learners become skilled judges of their own strengths and weaknesses and establish realistic and attainable goals for themselves, thus developing their self directed language learning ability (Chamot \& O’Malley, 1994; Dickinson, 1987; Oscarson, 1997).

A widely used instrument for self assessment is the portfolio. Portfolio assessment has been used extensively since mid '80s. The idea of using portfolios as an Instrument in performance-based assessment is not new. From past to present, especially painters, artists, writers, models and photographers have exhibited their vocational and acquired skills through portfolios (Zollman \& Jones, 1994).

In recent years, portfolios have been utilized for the same purposes, as an assessment instrument and as part of activities to improve students' foreign language skills. Portfolios provide an opportunity for English as a Foreign / Second language (EFL/ESL) learners to monitor their own progress and take responsibility for meeting goals.

By documenting growth over time through a systematic collection of their work, portfolios enable learners to see possibilities for reflection, redirection, and confirmation of their own learning efforts (O'Malley \& Pierce, 1996).

This study, aims to define the effects of portfolio assessment on EFL learners reading comprehension ability. Many educators, writers and researchers discuss the merits of using portfolios as an assessment instrument. For example, Calfee and Perfumo (1993) stress that using portfolios for assessment is important to show the learners' competence, rather than only choosing the correct answers and especially portfolio assessment provides more information about the learners, rather than just doing mechanical grading. Portfolios orient the students to produce various types of more authentic works and urge them to be more creative. Besides, portfolio assessment gives the learners more freedom and helps them develop and improve higher order thinking skills and meta-cognitive strategies.

Portfolios provide the students with the opportunity to see themselves not only as readers or writers, but also as individuals with special interests and needs, and provide students with unique opportunities to advance their learning.

\section{Statement of the Problem}

The purpose of this study is to investigate the effect of portfolio assessment on EFL learner's reading comprehension ability. Traditional assessment involves the employment of paper-and-pencil tests, standardized tests to assess student's performance under time pressure. There are several shortcomings and limitations among traditional testing methods. Traditional assessment is based on an interrelated set of philosophical beliefs and theoretical assumptions (Bintz, 1991).

One assumption of traditional assessment is that knowledge has a single consensual meaning (Berlak, 1992). It is possible for everyone to reach a consensus about meaning because knowledge has "the same meaning for all individuals everywhere" (Berlak, 1992, p. 13). But one assumption of alternative assessment is that knowledge has "multiple realities with accompanying multiple meanings" (Roderick, 1991, p. 3). It is impossible for everyone to reach a consensus about meaning because each individual brings his or her own diverse interpretation to an ever-changing situation. In traditional assessment, the metaphor of "empty vessel" is often used to talk about learners. Students are treated as if they do not possess prior knowledge about a topic. The instructor's role is "to 'fill' the students by making deposits of information which the instructor considers to constitute true knowledge" (Freire, 1990, p. 63). The focus is on learning about something rather than learning how to do something. This passive process involves students (novices) memorizing the knowledge dispensed by the text or instructor (expert). Alternative assessment treats learning as an active Process. In other words, learning entails "producing, rather than reproducing knowledge" (Newmann and Archbald, 1992, p. 72). Generally in traditional assessment, students' final products are evaluated based on some sort of test (Bertrand, 1993). In alternative assessment practices, the process is valued as well as the product. What, how, and why students learn is taken into consideration (Hutchings, 1993; Johnston, 1992).

Traditional assessment focuses on mastering discrete, isolated bits of information. These bits of information basically represent lower-level thinking skills (Engel, 1994; Herman, Aschbacher, and Winters, 1992), believed to exist in a hierarchical form. Students are expected to master and demonstrate specific skills at one level before moving on to the next. The focus of alternative assessment is on developing real-world problem-solving skills that will lead people to observe, think, question, and test their ideas (Herman, Aschbacher, and Winters, 1992).

Typically, traditional assessment is used only to monitor students' learning. Under this model, students who "know" 
are separated by those who "do not know." In other words, traditional assessment creates a system that classifies and ranks students (Berlak, 1992). The focus of alternative assessment is on developing real-world problem-solving skills that will lead people to observe, think, question, and test their ideas (Herman, Aschbacher, and Winters, 1992). The focus of traditional assessment is primarily on cognitive abilities. The values and interests that students have about the activity being undertaken are not considered to be connected to their competence in carrying out the task (Raven, 1992). Little, if any, attention is given to students' disposition to use the skills and strategies taught or their ability to apply them (Herman, Aschbacher, and Winters, 1992). Alternative assessment recognizes a Connection between Cognitive, Affective, and Conative Abilities. An assumption of alternative assessment is that "it is meaningless to attempt to assess a person's abilities except in relation to their valued goals" (Raven, 1992, p. 89).

Traditional assessment assumes that facts and values are distinct and separable entities that can be measured objectively (Berlak, 1992). Advocates of alternative assessment practices believe that decisions about what to teach and assess are subjective and value-laden (Bintz and Harste, 1994). "Indeed, value systems not only influence decisions about what assessment questions get answered, but also about what assessment questions get asked in the first place" (Bintz, 1991, p. 309). In traditional assessment, generally the instructor alone has the power to make decisions about what is learned and how it is assessed (Heron, 1988; Sessions, 1995). Students do not participate in making decisions about what is important for them to learn or in determining how well they are learning.

Alternative assessment embraces a democratic decision-making process (Heron, 1988). Traditional assessment focuses on an individual student's performance. Students are generally expected to accomplish tasks without the assistance of others, and if they get help they are cheating. Students often work against one another in a competitive manner. In contexts that use alternative assessment practices, students and instructors are co-learners, freely expressing and testing their ideas together.

In this social milieu, collaborative learning is valued, and instructors and students "are intellectually responsible to each other for creating a substantive curriculum in the classroom" (Bintz, 1991, p. 311).

There are many kinds of alternative assessment like portfolio assessment, play-based assessment, conference assessment, and soon... In this study just portfolio assessment will select as a tool and the skill be assessed is reading comprehension. Portfolio assessment provides an opportunity for EFl/ESl learners to monitor their own reading progress - their own learning strategies and take responsibility for meeting goals. Portfolio assessment can help learners to investigate their own strengths and weakness points. Portfolio assessment can evaluate students holistically based on the content of the portfolio on which the teachers and students agree. The portfolio can give students a chance to build up their experiences in language learning and this experience can motivate students to be more involved in the classroom because they feel that they have control in their own learning rather than just having the teachers tell them what they have to learn.

\section{Purpose of the Study}

The purpose of this study is to investigate the effect of portfolio assessment on EFL learners' reading comprehension ability. The educational system in Iran is based on traditional assessment and rote learning . These traditional testing and assessment are not authentic and don't demonstrate actual level of proficiency. Portfolio assessment helps students to monitor their progress and use their own portfolios for self-assessment and reflection. Portfolio assessment increases the meaningful learning. Teachers can also utilize them to judge students' performance. This study has aimed to enable teachers and students to share the responsibility for setting learning goals and for evaluating progress toward meeting those goals. This study helps students become self-directed and autonomous learners; teachers are no longer knowledge transmitters but mentors, facilitators and collaborators. Students can become active learners by taking more responsibility in learning and having more involvement in assessment.

\section{Research Questions}

According to the problems mentioned above, the following questions were posed: Is there any significant difference between the impact of traditional testing methods and portfolio assessment on EFL learners' reading comprehension ability? Does portfolio assessment have a positive effect on learners' reading comprehension ability?

\section{Research Hypotheses}

Based on a review of literature and the aforementioned lines of reasoning the following alternative hypotheses were formulated.

H1: There is no significant difference between the mean scores of the students in the experimental group who apply portfolio assessment and the mean scores of those students in the control group who do not apply portfolio assessment. 
H2: portfolio assessment does not have a positive effect on EFL learners' reading comprehensions ability in the experimental group at the end of the study and treatment.

H 3: Traditional assessment does not have a positive effect on EFL learners' reading comprehension ability at the end of the study.

\section{Significance of the Study}

With the realization of the fact that portfolios provide authentic evidence of what students know, believe, and are able to achieve, portfolios have become a desired tool for language education. The studies about the use of portfolio assessment in foreign language teaching largely show that they do improve writing skills. But, foreign language skills are not limited to writing skill alone. Reading, speaking and listening skills are also important.

The aim of this study is to find out the impact of portfolio assessment on reading skill. It might be possible to define the effects of portfolio assessment on reading skill in this research.

Reading is one of the four major skills in learning a foreign language and the one that provides the students with the best opportunity of being in contact with English after education. Our presupposition in this study is that students' difficulties in reading comprehension can be at least minimized if we use portfolio assessment for assessing of students because this way facilitates the learning process, enhances self-directed learning, encourages learner's autonomy, raises learner's awareness about learning strategies, and improve students' reading comprehensions ability .

\section{Definitions of Key Terms}

\subsection{Assessment}

The systematic process of gathering information about students' learning in order to describe what he or she knows, is able to do, and is working towards (Birjandi, 2000.).

\subsection{Test}

A test is a measurement instrument designed to elicit specific sample of an individual's performance (Bachman, 1995, p. 20).

\subsection{Formative Assessment}

Formative assessment is an assessment that specifically intended to generate feedback on performance to improve and accelerate learning. Formative assessment can be interpreted as encompassing all those activities undertaken by teachers, and / or by their students, which provide information to be used as feedback to modify the teaching and learning activities in which they are engaged.

\subsection{Summative Assessment}

Summative assessment takes place during the course of teaching and is used to provide information about how much students have learned and how well a course has worked (Gipps, 1994, p. vii).

\subsection{Self Assessment}

Self-assessment refers to how, under what conditions, and with what effects learners and other users of a foreign or second language may judge their own ability in the language. It employs a variety of techniques to probe language learners' proficiency, such as self- reports,-self-testing,-mutual peer assessment.

\subsection{Portfolio Assessment}

According to Yang (2003), portfolio is a compilation of student's work, which demonstrates how much effort they have put into their work, their progress and achievement in their learning, and their reflection on the materials chosen for the portfolio.

\subsection{Alternative Assessment}

It is a means of escaping the problems of multiple -choice testing. It requires students to perform in situations that are both life-like and complex (Frechling, 1991 cited in Cunningham, 1998. pp. 120-124).

\subsection{Washback}

Washback, sometimes referred to as backwash (Biggs, 1995, 1996 in Cheng, 2000), can be generally understood as the effect of an examination on teaching and learning (Chen, 2002; Hughes, 2003; Cheng, 2003).

\section{Methodology}

\subsection{Design of the Study}

A quantitative research was selected due to the nature of this research and the research questions. Besides, the 
appropriate design for this study was experimental. Two groups were selected. One group served as the experimental group and received treatment (portfolio assessment) while the other group served as the control group and received only the routine instruction. To ascertain the homogeneity of the two groups a language proficiency test was employed for this purpose. It should be mentioned that the control and the experimental groups were matched for everything except for the treatment. Both groups were 50 intermediate EFL students from a private English Language Institution. In order to measure the effectiveness of the treatment, the pretest/posttest design was selected. In this case, the control group took the same reading comprehension as pretest and posttest as did the experimental group, but did not receive the treatment. (Portfolio assessment)

\subsection{Participants}

50 students were chosen as the participants of this study from a private English Language Institution in Rasht. All of them were female and aged between 17-22 years old .They were divided into two groups of experimental and control each with 25 students. Both of these groups were almost equal regarding their general proficiency level and reading comprehension ability at the beginning of the study.

\subsection{Materials and Procedures}

According to the purpose of the study, a number of instruments for collecting the relevant data were used. One proficiency test was given to the students of both groups to see their levels and to make sure their homogeneity.

The Nelson300 D was selected for this purpose. Also two reading comprehension tests as pretest and post test were given to the students of both groups to find out their reading comprehension ability at the beginning and at the end of the instruction and the treatment. Steps book was selected for this purpose.

\subsubsection{Certain Procedures in Experimental Group}

In the first meeting with the participants of experimental group the researcher presented the idea of portfolio assessment, the purpose and the basic components of the portfolio, and weight it would have in their learning. The researcher also explained other types of alternative assessment such as self-assessment and peer assessment and their significance in the process of collecting portfolio. Another essential task in portfolio system is portfolio compilation . The students were asked to include these core and mandatory elements in their portfolios.

They were asked to complete 6 reading passages of various genres. Reading Log for each passage used as self -assessment tool for monitoring the reading comprehension and strategy use, questing students' progress over time ,evaluating the reading passages, reflections about the various reading challenges students faced, the different approached they experimented with, and summarizing the whole text into an appropriate reading strategy chart.( See Appendix 2 ); Student's Strategy Self-assessment Sheet in which the students graded their own portfolio pieces based on the assessment criteria assigned.(See Appendix 1).It should be mentioned that the control and the experimental groups were matched for everything except for the treatment.(portfolio assessment)

\subsection{Scoring}

The outmost scores for the general proficiency and reading comprehension tests were 50 and 20 respectively.

\subsection{Data Analysis}

The dependent and the independent variables of the study are the students 'reading comprehension ability and portfolio assessment respectively. According to the purpose of the study, a number of instruments for collecting the relevant data were used.

The data gathered on these variables were analyzed by the following methods through SPSS software.

- Descriptive Statistics was used to determine the mean and standard deviation of each group on the pre-and posttests.

- Independent t-test was used to find the difference between the levels of the students of both groups on posttests.

- Matched t-test was used to compare the two mean scores of the students of both groups in pre and posttest on reading comprehension test.

\section{Results and Discussion}

As it was mentioned before 50 intermediate EFL students were selected in this research. They were randomly assigned to experimental and control groups each with 25 students. In order to investigate the research questions and hypotheses the researcher used different procedures for collecting the relevant data.

At first a general proficiency test was given to the students of both groups to ensure the homogeneity of them and to investigate their initial levels. Then a reading comprehension test as pretest was given to the students of the two 
groups to find out their reading comprehensions ability at the beginning of the study.

After the instruction the researcher used a posttest: A reading comprehension test as posttest was given to the students of the two groups to find out their reading comprehensions ability at the end of the study and treatment. First the results of pretest and posttest in both groups presented in different tables, which include descriptive statistics as well as independent sample statistics and paired sample statistics. Finally the research questions and hypotheses reviewed and discussed by making reference to the statistical analysis achieved.

\subsection{Pretest Data}

After students took the reading comprehension pretest, the range, the minimum of the scores, the maximum of the scores, the mean scores, the standard deviations and the variances of both groups were calculated.

Table 1 represents the results. As table 1 shows the mean of the two groups is different in pretest, but the standard deviations of the two groups were similar at the beginning of the study. The result of pretest showed that the two groups were almost at the same level of reading comprehensions ability and the mean of the two groups were not of great difference.

\subsection{Posttest Data}

After giving treatment (portfolio assessment) to the experimental group and placebo to the control group, the research questions of the study was to be answered" is there any significant difference between the impact of portfolio assessment and traditional assessment on EFL learners' readings comprehensions ability? Does portfolio assessment have a positive effect on EFL learners' readings comprehensions ability "to answer these questions the researcher used two comparisons?

First the performances of the experimental group and the control group compared and second the performances of the experimental group and the control group in the pre and post test compared to investigate their progress and the influence of the portfolio and traditional assessment. After students took the reading comprehension posttest the range, the minimum of the scores, the maximums of the scores, the mean scores, the standard deviations and the variances of both groups were calculated.

Table 1. Group statistics

\section{Descriptive Statistics}

\begin{tabular}{|c|c|c|c|c|c|c|c|}
\hline & $\mathrm{N}$ & Range & Minimum & Maximum & Mean & Std. Deviation & Variance \\
\hline $\begin{array}{l}\text { pretest of control group for } \\
\text { reading }\end{array}$ & 25 & 4.40 & 11.61 & 16.01 & 13.6759 & 1.02261 & 1.046 \\
\hline $\begin{array}{l}\text { posttest of control group } \\
\text { for reading }\end{array}$ & 25 & 3.61 & 12.72 & 16.33 & 13.9157 & 1.01528 & 1.031 \\
\hline $\begin{array}{l}\text { pretest of experimental } \\
\text { group for reading }\end{array}$ & 25 & 4.41 & 10.94 & 15.34 & 12.8656 & 1.03928 & 1.080 \\
\hline $\begin{array}{l}\text { posttest of experimental } \\
\text { group for reading }\end{array}$ & 25 & 4.60 & 13.06 & 17.65 & 15.2431 & 1.17395 & 1.378 \\
\hline Valid N (listwise) & 25 & & & & & & \\
\hline
\end{tabular}

Table 1 represents the results. The posttest results show that there is a significant difference between the control and experimental group regarding their reading comprehensions ability. There is a significant difference between the mean of the two groups. In order to see this difference is meaningful the researcher made a $t$ test which is shown in the Table 2.

Table 2a and Table 2b. Independent samples test

\begin{tabular}{llrrrr}
\hline & group & $\mathrm{N}$ & & \multicolumn{1}{c}{ Mean } & \multicolumn{2}{c}{ Std. Deviation } & \multicolumn{2}{c}{ Std. Error Mean } \\
\hline \multirow{2}{*}{ score } & experimental group & 25 & 15.2431 & 1.17395 & .23479 \\
& control group & 25 & 13.9157 & 1.01528 & .20306 \\
\hline
\end{tabular}




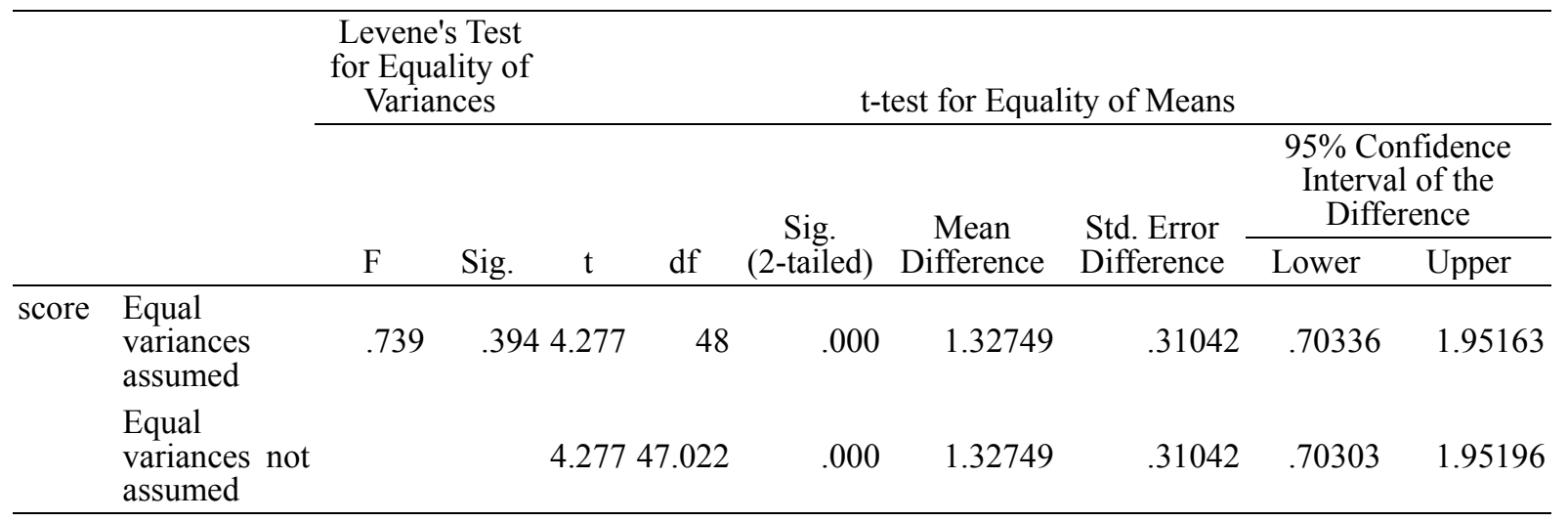

In this table as it is seen the $t$ observed is 4.277 and $t$ critical at our selected significance level of 0.05 for degree of freedom 24 is 2.064 . The $t$ observed is higher than the $t$ critical.

As table shows the post test results reject the first null hypothesis and it was concluded that there is a significant difference between the experimental and the control group in terms of their reading comprehensions ability at the end of the study.
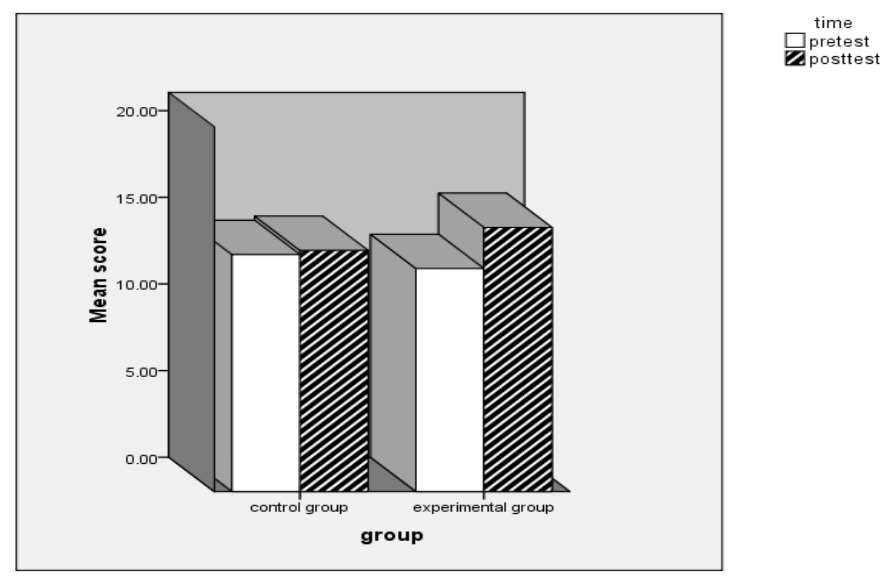

Figure 1. Bar graph of the two groups in pre and posttest

Figure 1 shows the bar graph of means of pretest and posttest in the two groups. As it is seen in figure 1 the mean scores of posttest of the experimental group is higher than the mean scores of their pretest, and it can be concluded that there is a significant progress from the pretest to the posttest. Also there is not a significant progress in the performances of the control group from the pretest to the posttest.

The statistical technique used to investigate the second and third hypotheses was paired t-test.

Table 3a and Table 3b. Paired samples analysis of the control group

Paired Samples Statistics

\begin{tabular}{lllllrr}
\hline & & Mean & $\mathrm{N}$ & Std. Deviation & Std. Error Mean \\
\hline Pair 1 & $\begin{array}{l}\text { pretest of control group for } \\
\text { reading }\end{array}$ & 13.6759 & 25 & 1.02261 & .20452 \\
\hline $\begin{array}{l}\text { posttest of control group for } \\
\text { reading }\end{array}$ & 13.9157 & 25 & 1.01528 & .20306 \\
\hline
\end{tabular}


Paired Samples Test

\begin{tabular}{|c|c|c|c|c|c|c|c|}
\hline & & \multicolumn{5}{|c|}{ Paired Differences } & \multirow{3}{*}{ df $\underset{\text { (2-tailed) }}{\text { Sig. }}$} \\
\hline & & \multirow{2}{*}{ Mean } & \multirow{2}{*}{$\begin{array}{c}\text { Std. } \\
\text { Deviation }\end{array}$} & \multirow{2}{*}{$\begin{array}{l}\text { Std. Error } \\
\text { Mean }\end{array}$} & \multicolumn{2}{|c|}{$\begin{array}{l}\text { 95\% Confidence Interval of } \\
\text { the Difference }\end{array}$} & \\
\hline & & & & & Lower & Upper & \\
\hline $\begin{array}{l}\text { Pair } \\
1\end{array}$ & $\begin{array}{l}\text { pretest of control group for } \\
\text { reading - posttest of } \\
\text { control group for reading }\end{array}$ &.-23980 & .67941 & .13588 & -.52025 & .04065 & -1.76524 \\
\hline
\end{tabular}

Table 3a displays mean value, number of cases, standard deviation, and standard error of means in the control group.

Table $3 \mathrm{~b}$ represents the paired t-test statistics of the control group in pre and post-test: It is clear in Table $3 \mathrm{~b}$ there is a little progress between the performances of the control group from pretest to posttest . The t observed is less than the $t$ critical and it was concluded that the third null hypotheses was supported .Traditional assessment does not have a positive effect on EFL learners' reading comprehensions ability.

Table $4 \mathrm{a}$ and Table $4 \mathrm{~b}$. Paired samples analysis of the experimental group

Paired Samples Statistics

\begin{tabular}{lllrrr}
\hline & Mean & N & Std. Deviation & Std. Error Mean \\
\hline Pair 1 & $\begin{array}{l}\text { posttest of experimental group } \\
\text { for reading }\end{array}$ & 15.2431 & 25 & 1.17395 & .23479 \\
& $\begin{array}{l}\text { pretest of experimental group for } \\
\text { reading }\end{array}$ & 12.8656 & 25 & 1.03928 & .20786 \\
\hline
\end{tabular}

Paired Samples Test

\begin{tabular}{|c|c|c|c|c|c|c|c|}
\hline & \multicolumn{4}{|c|}{ Paired Differences } & \multirow[b]{3}{*}{$\mathrm{t}$} & \multirow{3}{*}{$\begin{array}{c}\text { Sig. } \\
\text { df }\end{array}$} \\
\hline & & \multirow{2}{*}{$\begin{array}{c}\text { Std. } \\
\text { Deviation }\end{array}$} & \multirow{2}{*}{$\begin{array}{l}\text { Std. } \\
\text { Error } \\
\text { Mean }\end{array}$} & \multicolumn{2}{|c|}{$\begin{array}{l}95 \% \text { Confidence } \\
\text { Interval of the } \\
\text { Difference }\end{array}$} & & \\
\hline & & & & Lower & Upper & & \\
\hline & $\begin{array}{l}\text { posttest of experimental group } \\
\text { for reading - pretest of } 2.37751 \\
\text { experimental group for reading }\end{array}$ & .30653 & .06131 & 2.25098 & 2.5040 & 38.781 & .000 \\
\hline
\end{tabular}

Table 4a displays mean value, number of cases, standard deviation, and standard error of means in the experimental group.

Table $4 \mathrm{~b}$ represents the paired t-test statistics of the experimental group in pre and post-test:

It is clear from Table $4 \mathrm{~b}$ the observed $\mathrm{t}$ is 38.781 which was greater than the critical value 2.064 , thus it was concluded that there is a significant difference between the means of the two sets of scores. In other words, the difference between the performance of the experimental group on pre and post-test was statistically significant.

The based on the results the second null hypotheses was rejected and it was concluded that there is a significant difference between the impacts of traditional and portfolio assessment on EFL learners reading comprehensions ability and portfolio assessment has a positive effect on the experimental group' progress in their reading comprehension ability at the end of the study.

\section{Conclusion}

Results of hypotheses testing investigated that there is a significant difference between the performance of the two groups .Before the program, there was not a statistically significant difference between the control group and experimental group in terms of their reading comprehensions ability.

At the end of the study, there was statistically a significant difference between the performances of the two groups in 
terms of their reading comprehensions ability. The comparisons made showed that the reading comprehension of those students in the treatment group where portfolio assessment implemented differ significantly from those of students in the control group where traditional assessment implemented.

Finally findings of the study reject the first and the second null hypotheses and the third null hypotheses was supported .It was concluded that there is a significant difference between the impact of portfolio assessment and traditional assessment on EFL learners' reading comprehension ability and portfolio assessment has a positive effect on EFL learners' reading comprehension ability. The findings of this study are in agreement with the existing studies in the literature which revealed that portfolio assessment methods could enhance students' achievements. It is also in line with the findings of all the studies showing the usefulness of involving students in the process of their own assessment as well as providing feedback in instruction.

\section{Implications of the Study}

The results of the present study have several important implications.

1: this study enables teachers and students to share the responsibility for setting learning goals and for evaluating progress toward meeting those goals and helps students become self-directed and autonomous learners, teachers are no longer knowledge transmitters but mentors, facilitators and collaborators. Students can become active learners by taking more responsibility in learning and having more involvement in assessment.

2: syllabus designers can get the insight from the results of this study in designing an appropriate syllabus .Syllabus designers should also consider and value learners' right for their own decisions and suggestions and criticism while designing syllabuses.

3: the result of this study can provide specific details about students 'success and failure for their parents

4: portfolios can also be used as an assessment tool; students' future teachers can use them to judge students' performance. Also students can use their own portfolios for self-assessment and reflection.

5: findings of this study promote the meaningful learning and decrease the problems of the rote learning.

6: the findings of this study might be applicable to the assessment of all language skills and sub-skills such as listening, speaking, pronunciation, vocabulary, grammar and so on.

7: the present study also showed that alternative assessment techniques such as self assessment are useful in teaching and meaningful learning.

8: portfolios can be used for measuring students' performance based on genuine samples of student work.

9: findings of this study showed that portfolios have an important role in EFL instruction. Portfolio assessment in EFL instruction helps students to find appropriate Learning contexts for themselves during foreign language learning helps learners to identify their goals for their future learning. Helps them to exhibit their good work and gives them the opportunity to take responsibility for their own learning. Portfolio assessment also enables EFL teachers to identify effective language teaching strategies and reflect on the program carried on in classes. Portfolio assessment provides information about language learning processes of students and facilitates the teacher to individualize the teaching.

10: the findings of this study may be applied to all educational fields and in all educational settings where the aim is to increase the meaningful learning and to promote students' role in assessment and decision making.

\section{Limitations of the Study}

There have been some limitations in conducting this study:

1: In this study the researcher was in the shortage of time, the study lasted only ten weeks.

2: The study was conducted only with 50 students of intermediate level of proficiency in a private language institute in Rasht.

3: The researcher also had to select only from female students.

4: Among all skills of language, reading has been taken into account.

5: The researcher did not consider the impact of psychological factors such as intelligent, anxiety and motivation on students' learning.

6: The researcher also had to select the texts from their own books because the institute didn't let her to use her own texts. 


\section{Suggestions for Further Studies}

The following suggestions are presented for those who are willing to contribute to the present study by conducting studies on the impact of portfolio assessment on students' learning.

Firstly ,This study was conducted to investigate the impact of portfolio assessment on EFL learners' reading comprehension ability, interested researchers can investigate the impact of using portfolio assessment on other language skills such as listening, writing and speaking.

Secondly, this study was conducted for EFL intermediate students; it can be replicated with other levels such as elementary or advanced. Thirdly, interested researchers can investigate the impact of other types of alternative assessment techniques on language skills such as peer-assessment, self-assessment, etc.

Also it would be fruitful to investigate the relationship between portfolio assessment and students' motivation or anxiety.

Finally the participants of this study were all female with average age of 17-22 years old .Similar studies can change variables of age and gender.

\section{References}

Boud, D. (1995). Enhancing learning through self assessment. Kogan Page,London.

Bintz, W. P. (1991). “'Staying Connected': Exploring New functions for Assessment.” Contemporary Education, 62(4), 307-312.

Bintz, W. P., \& Harste, J. (1994). Where Are We Going with Alternative Assessment? And Is ItReally Worth Our Time? Contemporary Education, 66(1), 7-12.

Berlak, H. (1992). The Need for a New Science of Assessment. In H. Berlak and others (eds.), Toward a New Science of Educational Testing and Assessment. Albany: State University of New York. Retrieved from books.google.com

Bertrand, J. E. (1993). Student Assessment and Evaluation. In B. Harp (ed.), Assessment and Evaluation in Whole Language Programs. Norwood, Mass: Christopher-Gordon. Retrieved from www.jcu.edu/.../planassess/.../Assessment\%20Resources/.../

Chamot, A. U., \& O'Malley, J. M. (1994). The CALLA Handbook: Implementing the Cognitive Language Learning Approach. Reading, MA: Addison Wesley. Retrieved from jillrobbins.com/calla/references.html

Calfee, R., \& Perfumo, P. (1993). Student portfolios: Opportunities for a revolution in assessment. Journal of Reading, 36(7), 532-537. Retrieved from books.google.com/books?isbn=0125541554

Chen, Y. M. (2005). Peer and Self-Assessment in EFL Classrooms. Selected Papers of the Fourteenth International Symposium on English Teaching (pp. 320-329).Taipei: Crane Publishing.

Crooks, T. (1988). The impact of classroom evaluation on students. Review of Educational Research, 58(4), 438-481.

Crooks, T. (2001).The validity of formative assessment. Paper presented to the British Educational Research Association Annual Conference, University of Leeds, 13-15.

Collins, J., \& OBrien, N. (2003). The Greenwood Dictionary of Education. USA, Westport: Greenwood Press. September, 2001. Retrieved February 24, 2007, from: http://www.leeds.ac.uk/educol/documents/00001862.htm

Dickinson, L. (1987). Selfinstruction in Language Learning. Cambridge: Cambridge University Press. Retrieved from applij.oxfordjournals.org/content/19/3/378.full.pdf

Engel, B. S. (1994). Portfolio Assessment and the New Paradigm: New Instruments and New Places. The Educational Forum, 59, 22-27. Retrieved from www.tandfonline.com/doi/abs/10.1080/00131729409336359. http://dx.doi.org/10.1080/00131729409336359

Freire, P. (1990). Pedagogy of the Oppressed. New York: Continuum.

Gronlund, N., \& linn, R. (1990). Measuremen and Evaluation in teaching. NewYork:Macmillan.

Hutchings, P. (1993). Principles of Good Practice for Assessing Student Learning. Assessment Update, 5(1), 6-7. http://dx.doi.org/10.1002/au.3650050104

Herman, J. L., Aschbacher, P. R., \& Winters, L. (1992). A Practical Guide to Alternative Assessment. Retrieved from www.e-lead.org/principles/structure.asp

Heron, J. (1992). Assessment Revisited. In D. Boud (ed.), Developing Student Autonomy in Learning (2nd ed.). New 
York: Nichols.

Johnston, P. H. (1992). Constructive Evaluation of Literate Activity. White Plains, N.Y.: Longman. Retrieved from www.albany.edu/cela/reports/allington/allington4thgrade13010.pdf

Newmann, F. M., \& Archbald, D. A. (1992). The Nature of Authentic Academic Achievement. In H. Berlak and others (eds.), Toward a New Science of Educational Testing and Assessment. Albany: State University of New York.

Oscarsson, M. (1997). Selfassessmentof foreign and second language proficiency. In C. Clapham and D. Corson (eds), Encyclopedia of Language and Education, Volume 7: Language Testing and Assessment (pp. 175-187). Netherlands: Kluwer AcademicPublishers.

O’Malley, M. J., \& Valdes Pierce, L. (1996). Authentic assessment for English language learners: Practical approaches for teachers. New York: Addison Wesley Publishing Co.

Pressley, M., \& Ghatala, E. S. (1990). Self-regulated learning: Monitoring learning from text. Educational Psychologist, 25, 19-33. http://dx.doi.org/10.1207/s15326985ep2501_3

Roderick, J. A. (1991). (ed.) Context-Responsive Approaches to Assessing Children's Language. Urbana, Ill.: National Conference on Research in English.

Raven, J. (1992). A Model of Competence, Motivation, and Behavior, and a Paradigm for Assessment. In H. Berlak and others (eds.), Toward a New Science of Educational Testing and Assessment. Albany: State University of New York.

Sessions, R. (November 1995). Education is a Gift, Not a Commodity. Paper presented at the National Conference of the Community Colleges Humanities Association, Washington, D. C. Retrieved from www.jcu.edu/academic/.../Different\%20ways\%20to\%20Grade.pdf

Stiggins, R. (2001). Student- Involved Classroom Assessment (3rd ed). N.J., Upper Saddle River Prentice-Hall.

Zollman, A., \& Jones, D. L. (1994). Accommodating assessment and learning: Utilizing portfolios in teachers education with preservice teachers. Paper presented at the Annual Conference of the Research Council on Diagnostic and Prescriptive Mathematics, 21st, Fort Worth, TX. (ERIC Document Reproduction Service No. ED368551). Retrieved from ERIC database.

\section{Appendix 1. Student's Strategy Self-assessment Sheet}

Please put check mark in the box if you used the following strategies to understand each reading passage.

\begin{tabular}{|l|l|l|l|l|l|l|l|}
\hline Reading's strategies & R1 & R2 & R3 & R4 & R5 & R6 & $\begin{array}{l}\text { Student' } \\
\text { score }\end{array}$ \\
\hline I use my background knowledge. & & & & & & & \\
\hline $\begin{array}{l}\text { I Use context as well as parts of words (e.g. } \\
\text { prefixes, suffixes, and stems)to work out the } \\
\text { meaning of unknown words }\end{array}$ & & & & & & \\
\hline $\begin{array}{l}\text { I look quickly through a text in order to locate } \\
\text { specific information }\end{array}$ & & & & & & \\
\hline $\begin{array}{l}\text { I Look through the text to get a general idea of what } \\
\text { is about. }\end{array}$ & & & & & & \\
\hline
\end{tabular}

\section{Appendix 2. Student's Reading Log}

\begin{tabular}{|c|l|l|l|l|}
\hline $\begin{array}{l}\text { My progress in reading } \\
\text { comprehension }\end{array}$ & Date and time & $\begin{array}{l}\text { Student 'self -assessment after } \\
\text { every reading }\end{array}$ & $\begin{array}{l}\text { Purpose: increasing the level of } \\
\text { reading comprehension ability }\end{array}$ \\
\hline $\begin{array}{c}\text { Excellent } \\
\text { Good }\end{array}$ & My problem & $\begin{array}{l}\text { The strategy I } \\
\text { used and how } \\
\text { did it help me }\end{array}$ & \\
Try more & & & \\
\hline
\end{tabular}

Report of the story

How do you evaluate the text?

Did you have any background knowledge about the text?

Summarize the text 